\title{
Biodiversity and Management Status of Charia Beel in Northern
}

\section{Bangladesh}

\author{
B. K. Chakraborty ${ }^{1}$, S.N. Labh ${ }^{2}$, R. Rani ${ }^{3}$, S. Bhattacharjee ${ }^{1}$ \\ ${ }^{1}$ Department of Fisheries, Bangladesh and Culture of mud eel, mud crab, aquaculture and \\ management centre. \\ ${ }^{2}$ Tribhuvon University, Nepal. \\ ${ }^{3}$ Bangladesh Agricultural University.
}

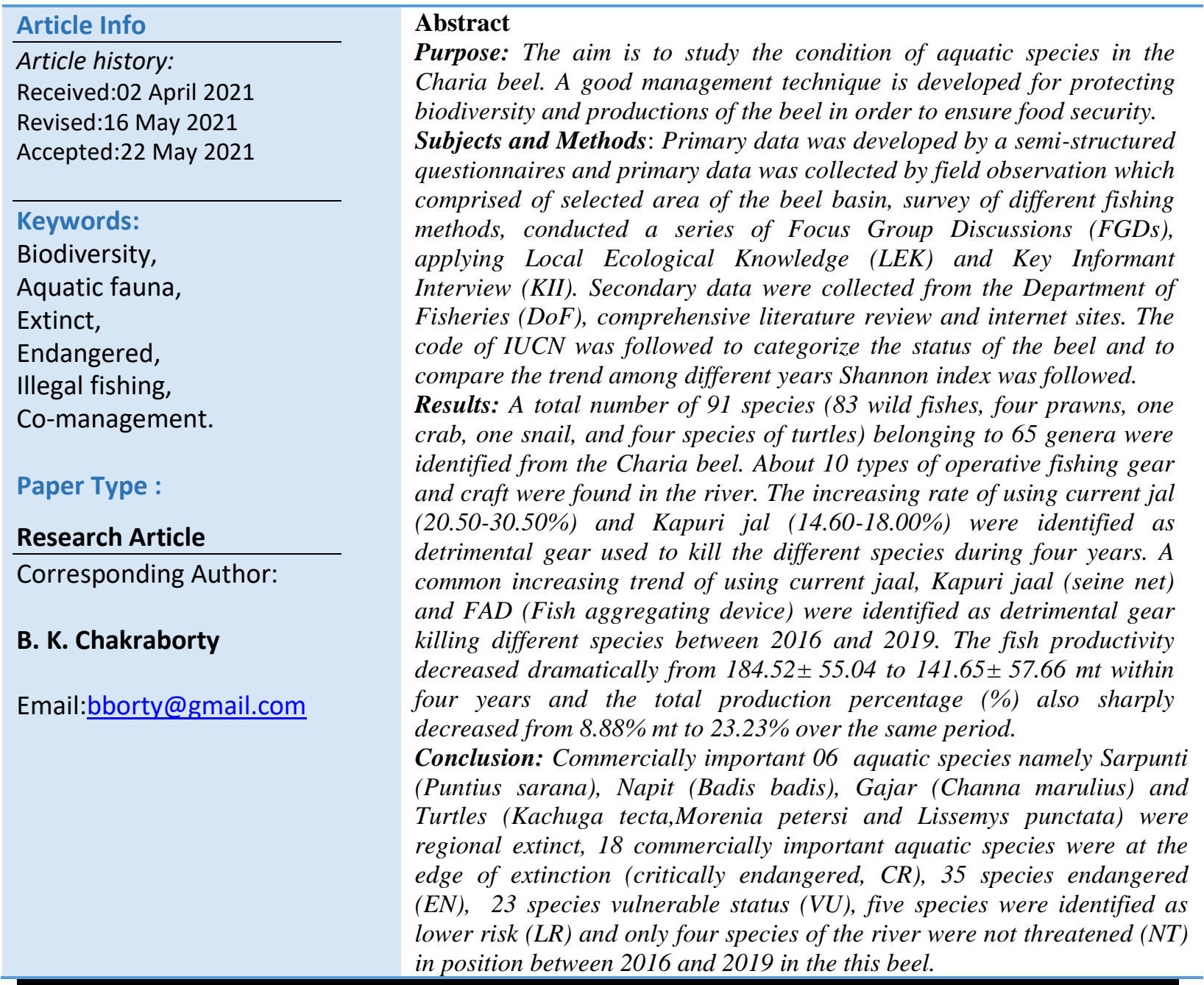

\section{Introduction}

River ecosystems encompass ecological, social and economic processes that interconnect organisms including humans and helpful in maintaining biodiversity. Biodiversity has different levels and values (Verma, 2016; Chakraborty et al. 2021). Biodiversity helps in maintaining the ecological balance. There is a necessity of ecological balance for widespread biodiversity (Ashok, 2017a) and the ecological balance is an 
indispensable need for human survival (Verma, 2018; Chakraborty et al. 2021). Biodiversity conservation and environmental ethics both are required for the sustainable development and survival of plants and animals because biodiversity is the foundation of human life (Ashok, 2019; Verma and Prakash, 2020).

The study of biodiversity has become a major concern to the fishing biologists against the backdrop of rapid decline in the natural population of fish and aquatic biota across all the continents of the world. Biodiversity encompasses genetic species, assemblage, ecosystem and land cape levels of a biological organization with structural, compositional and functional components (Noss, 1983; Crains and Lackey, 1992). Genetic diversity acts as a buffer for biodiversity (Ashok, 2017b). Though loss of aquatic species has been occurring rapidly, the aquatic organisms have received comparatively little attention from conservation biologists (Allendorf, 1988). A rich diversity of fish species is critical to the ecology and sustainable productivity of the flood plains (Praksh and Verma, 2019; Prakash et al., 2020). The resource of aquatic fauna in Bangladesh are under severe threat due to over-exploitation and environmental degradation, which includes human interventions through the construction of flood control embankments, drainage structures and sluice gates, conversion of inundated land to cropland thereby reducing water area and indiscriminate use of pesticides. Pollution from domestic, industrial and agrochemicals wastes and run off have resulted in the extinction of a considerable amount of aquatic biota in the same stretches of the open water system (Disaster, 1990).

In Bangladesh, the beels are important fishing grounds. Once, these beels (wetland) had abundant of native wild fish species, prawns, snail, crabs, and turtles. Due to overexploitation and various ecological changes of the beel (wetland), indiscriminate destructive fishing practices, soil erosion, siltation, construction of flood control and drainage structures and agro-chemicals have caused havoc to the aquatic biodiversity in Bangladesh (Hussain and Hossain, 1999). The beel receives surface runoff water by rivers and channel (khal), and consequently, a beel becomes very extensive water body in the monsoon and dries up mostly in the post-monsoon period (Chakraborty et al., 2021, 2019; Chakraborty and Mirza, 2010).

During the monsoon, the beels get inundated and become part of seasonal floodplain resources with abundant aquatic vegetation. However, through gradual sedimentation, the basin becomes shallower leading to the formation of reeds and sedges. This resulted in providing enough food and shelter for fish and other aquatic fauna, and added fertilizer to the crop land of the beel which promoted rich growth of phytoplankton and macrophytes thus partly contributing to the process of eutrophication. The basin of the beel supports a large variety of wetland biodiversity and works as a natural reservoir as it plays a key role in basin water resources by regulating water flows of the different river systems. In the past century or so, when the human population pressure of Bangladesh was less, most of the rim-lands of the beel remained as cultivable wasteland which was mainly used for extensive grazing in the dry season. As the population increased, boro cultivation expanded on these marginal lands leading to a large area being drained. Thus, the existence of these wetlands of the beels is now threatened (Chakraborty, 2009).

Owing to a massive loss in aquatic biodiversity, a well-planned and systematic study is required to assess the present status of biodiversity in the beels of Bangladesh to take appropriate action to preserve and manage the aquatic fauna. The present study focuses on 
the abundance, species combination, catch statistics and related aspects of Charia beel. Based on present physiographic conditions of the beel, a cost-effective fish fingerlings production technique is developed through co-management community approach which leads to enhance the biological productivity of the recorded beel.

\section{Material and Methods}

\section{Location and area of the beel}

The Charia beel comprised an average area of 1050 ha. The beel is surrounded by Kamaria village in the east, Kodomtoli village in the west and North and Haripur village in the South, under Fhatepur union, Sadar Upazilla, in Mymensingh district (Fig. 1).

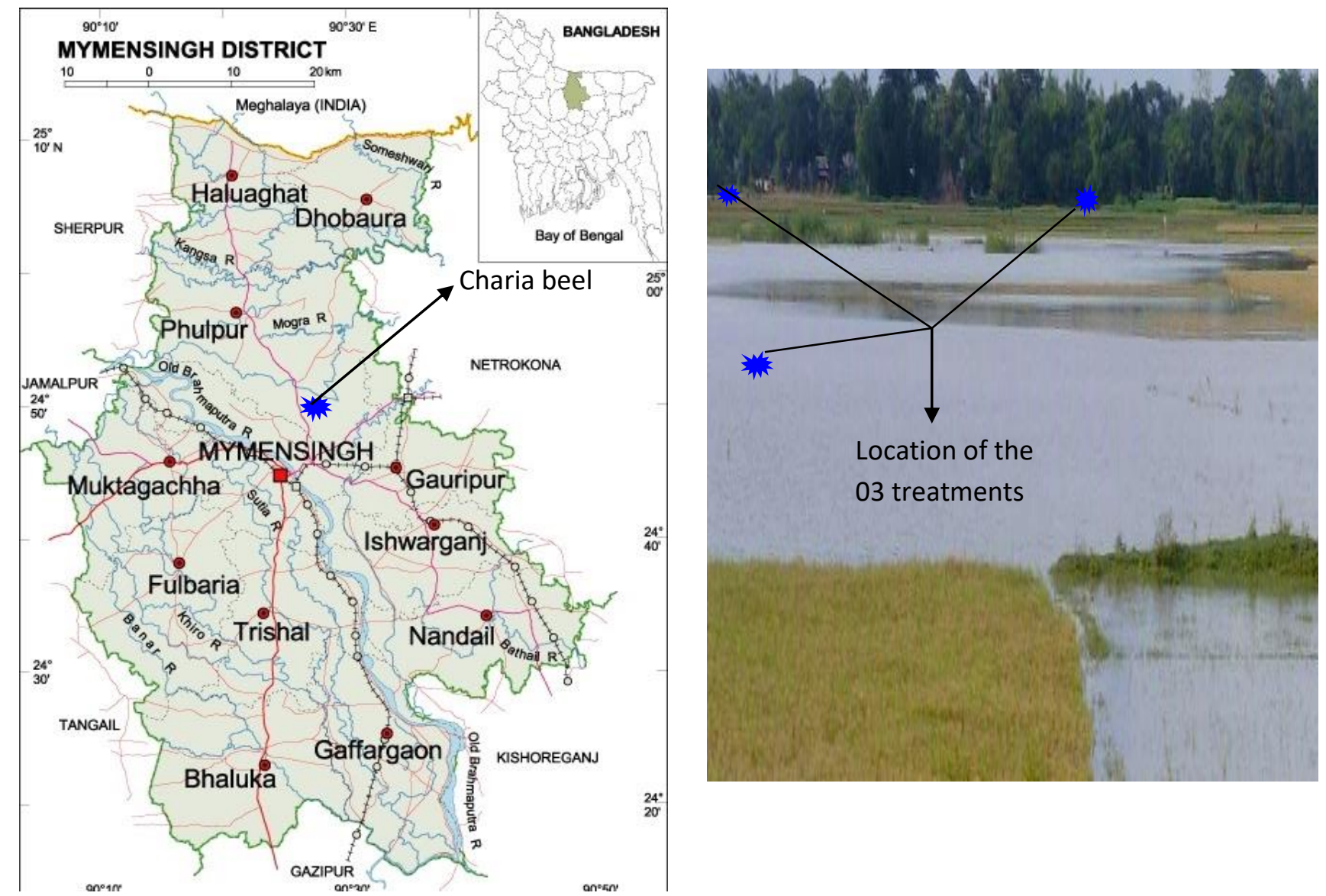

Fig. 1. Map of Bangladesh and Netrokona district showing the location of Charia beel with three treatments.

\section{Experimental procedure}

Detail survey on the flora and fauna of the Charia beel was conducted during 20162019 with particular emphasis on soil and water quality, biological productivity and biotic communities and status of fishery exploitation. The research was operationalized through a collection of both primary and secondary data. Collection of primary data was developed by a semi-structured questionnaires and primary data was collected by field observation which comprised of selected area of the beel basin, survey of different fishing methods, conducted a series of Focus Group Discussions (FGDs), applying Local Ecological Knowledge (LEK), 
Key Informant Interview (KII) a survey of fish market adjacent to waterbody, depot holders and monitoring feeding and breeding ground, monitoring of hydrological, meteorological, physico-chemical and biological characteristics of beel and fishers' perception as well. Secondary data were collected from the Department of Fisheries (DoF), comprehensive literature review and internet sites.

\section{Morphometry and hydrodynamics of experimental eel}

Generally, the main sources of water input into the Charia beel ecosystem was viz. overspill from the river channel, surface flow and regeneration. Water flows were determined by both rainfall and flooded water from the Meghaloya's hilly range, India. This beel is connected with the Brahmaputra River by a cannel (khal). In the dry season, almost $50 \%$ of beel areas was dried up, and khata and kua fishing area where water remains during January to mid-April. Flooding of the recorded beel was originated from the inflow of water from the Brahmaputra River causing resumption of connection between beel, and canal and river. The accumulation or exchange of water took place during southwest monsoon when floodplains were flooded. The early flood phase (April to early June) occurred in the early monsoon when the water level in the basin was relatively low. The water level in the beel rose and fell in accordance with the water level in adjacent floodplains and adjacent river. Floodwater in flood plains started receding in the post-monsoon season (October to December). The deep flood phase (June to September) begins when the water level in the Brahmaputra River registers a rapid rise, causing deep flooding in the area of the surveyed beel. Floodwater in floodplains of the Charia beel started receding in the post-monsoon season (October to December). After the recession of flood, the water level in the beel decreased snapping the beel connection with the river. When the surface area of the beel shrank, fishes and other aquatic organisms move with water flow into deep water area of the beel. The beel gets almost dried up through evapo-transpiration and seepage. Except the deeper portion of the beel, most of the margin was brought under rice cultivation by extracting water from the beel. The water lost by various means caused shrinkage of the effective water area and lowering of depth in the beel which affected the status of the aquatic biodiversity of the Chariabeel.

\section{Study of Physico-Chemical Parameters}

Physico-chemical parameters were followed by the standard method of APHA (1998). A bamboo-made meter scale was used to measure water depth. Water temperature was measured using a Celsius thermometer and transparency was recorded by using a Secchi disc of $20 \mathrm{~cm}$ diameter. Dissolved oxygen and $\mathrm{pH}$ were calculated directly using a digital electronic oxygen meter (YSI Model 58) and an electronic pH meter (Jenway Model 3020). Alkalinity was recorded by the titrimetric method (Clesceri et al.,1989).

\section{Fishing Method}

Detail survey on the fishing method of the Charia beel was conducted with particular emphasis on the number of different gears and traps. Fishers' used boat for transport of nets and related materials and used ber jal (seine net), komor jal (seine net, used for Khata fishing), thela jal (Push net), bua jal (small lift net), lift net, cast net, current jal (Gill net), 
various type of fish traps, hook and lines; and fishing by dewatering FAD (Fish aggregating device) according to season and availability of different species of fish. During monsoon and post-monsoon, fisher's used lift net, current jal, cast net, traps (vair, dugair, ghuni, pholo, etc) hook and lines (barsi, fulkuichi, jhupi,, aikra, etc.) to catch fishes. They also operated kata fishing by sein net (Ber jal and Komor jal) in winter and springseasons.

\section{Data Collection}

An organized sampling program was run for a long time to get a true picture of the catch and catch composition of surveyed beel. The experimental beel were sampled during winter (mid-November to mid-February), pre-monsoon (mid-February to April), monsoon (May to August) and post-monsoon (September to mid-November) for assessment of aquatic lives' abundance and availability. The current study, being a rapid survey, gives only a broad picture of a stock of fishes, prawn, crabs, snail and turtles' that was recorded through fish landing centers and different market survey, collection of different species directly from fishers' catch,fishing through the enclosure with bana fence (made by bamboo), khata fishing and interaction with fishers' in the beels. Resident fish species was recorded through fishing in the deep pool areas (man-made kuas) where water remains during dry season (January to mid-April). The number of six codes (CR, E, EN, VU, LR and NO) of IUCN was followed to categorize the status of the beel and to compare the trend among different years Shannon index was followed by Shannon (1948).

\section{Shannon Diversity Index:}

$$
\begin{aligned}
& \mathrm{S}=\sum-\left(\mathrm{P}_{\mathrm{i}} * \ln \mathrm{P}_{\mathrm{i}}\right) \mathrm{i}=1 \\
& \text { Where: } \\
& \mathrm{H}=\text { the } \text { Shannon diversity index } \\
& \mathrm{P}_{\mathrm{i}}=\text { fraction of the entire population made up of species } \\
& \mathrm{S}=\text { numbers of species encountered } \\
& \sum=\text { sum from species } 1 \text { to species } \mathrm{S}
\end{aligned}
$$

Note: The power to which the base e $(e=2.718281828 \ldots \ldots . .$.$) must be raised to obtain a$ number is called the natural logarithm $(\ln )$ of the number.

\section{Analysis of experimental data}

The data were analyzed through one-way ANOVA using MSTAT followed by Duncan's Multiple Range Test to find out whether any significant difference existed among treatment means (Duncan, 1955; Zar, 1984). Standard deviation in each parameter was calculated and expressed as mean \pm S.D.

\section{Results and Discussion}

\section{Physical characteristics of Charia beel}


The soil texture of Charia beelbed varied from clay to sandy sand. In the deeper bed, the structure of soil texture of the bed appeared to have predominantly clay and in the wet land bed the soil was found to be sandy to loam

Table 1. Physical features (sediment) of the surveyed Charia beel.

\begin{tabular}{lllll}
\hline \multirow{2}{*}{$\begin{array}{l}\text { Name of } \\
\text { the beel }\end{array}$} & Location & \multicolumn{3}{l}{ Soil texture of the bed of beel $(\%)$} \\
\cline { 3 - 5 } & & Clay & Loam sand & Sandy \\
\hline Charia & Deeper bed & $72.2 \pm 3.08^{\mathrm{a}}$ & $28.3 \pm 2.11^{\mathrm{b}}$ & $1.5 \pm 0.15^{\mathrm{c}}$ \\
beel & Wet land bed & $20.2 \pm 2.28^{\mathrm{b}}$ & $81.5 \pm 4.85^{\mathrm{a}}$ & $2.3 \pm 0.45^{\mathrm{c}}$ \\
\hline \multicolumn{4}{l}{ Figures with different superscripts in the same row differed significantly $(P>0.05)}$.
\end{tabular}

sand (Table 1). The highest percentage $(72.2 \pm 3.08 \%)$ of clay was recorded in the deeper bed of Charia beel respectively. On the other hand, the highest percentage $(81.5 \pm 4.85 \%)$ of loam sand in the wet land bed of the recoded beel was identified. The soil structure of the deeper bed appeared to have predominantly clay and in the surrounding area of the wet land was loamy to clay.

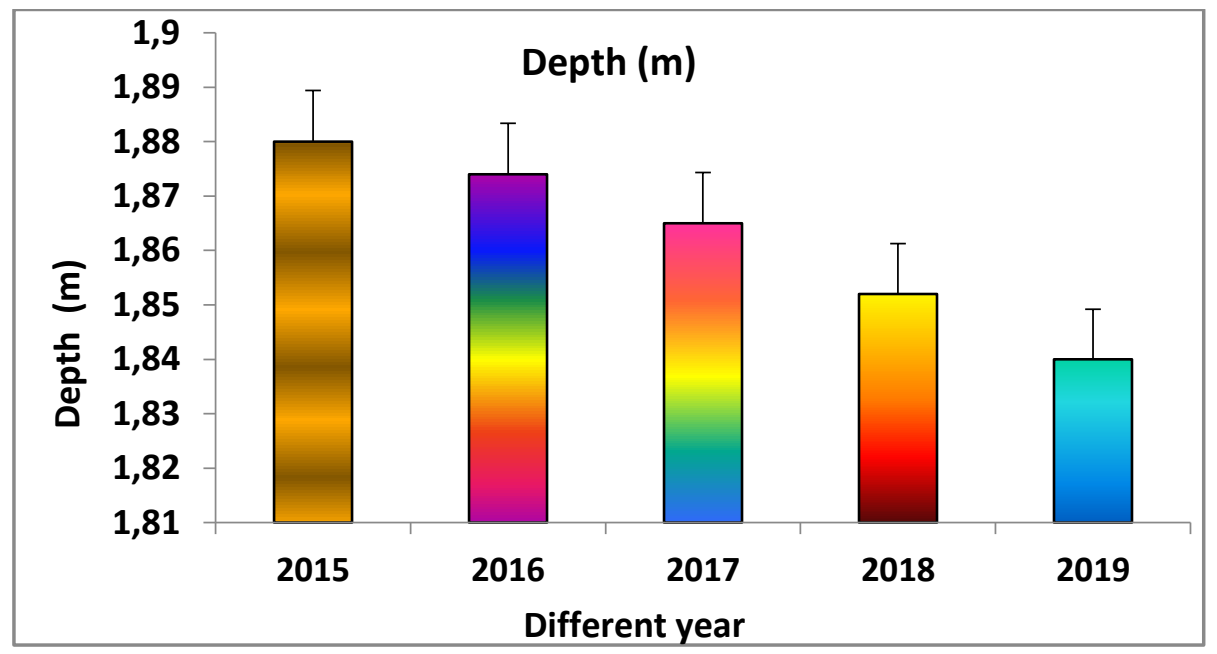

Figure 2: Water depth of the experimental Charia beel between the years 2016-2019.

The water depth of the Charia beel varied from 1.88 to $1.84 \mathrm{~m}$ during the year 2016-2019, respectively. The highest depth of the surveyed beel was recorded in the year 2016 and the lowest depth was found in 2019. There was a tendency to decrease the depth of the beel bed shallow to shallower between 2016 and 2019 (Fig. 2) due to siltation and sedimentation.

\section{Physico-chemical parameters}

The results of the physico-chemical parameters of the Charia beel is furnished in Table 2 which included temperature, transparency, $\mathrm{pH}$, dissolved oxygen and alkalinity of water were found to be more and less in a normal range. is evident from Table 2 that the mean water temperature of the aquatic environment of the beel was not statistically significant $(\mathrm{P}>0.05)$. Mean Secchi disk transparency differed significantly $(\mathrm{P}<0.05)$, during the years 2016 to 2019. Higher values occurred during post-monsoon and summer months due to reduced flow and relatively stable conditions of the water. $\mathrm{pH}$ of the experimental beel did not differ significantly $(\mathrm{P}>0.05)$. 
Table 2. Physico-chemical parameters of recorded Charia beel.

\begin{tabular}{lcccc}
\hline \multirow{2}{*}{ Parameters } & \multicolumn{4}{c}{ Study years } \\
\cline { 2 - 5 } & 2016 & 2017 & 2018 & 2019 \\
\hline Temperature & $25.24 \pm 8.08$ & $26.11 \pm 6.51$ & $25.62 \pm 7.47$ & $24.86 \pm 7.12$ \\
$\left({ }^{\circ} \mathrm{C}\right)$ & $(14.44-32.77)$ & $(14.55-32.82)$ & $(14.05-32.85)$ & $(15.20-32.95)$ \\
Transparency & $42.55 \pm 7.14^{\mathrm{d}}$ & $35.18 \pm 6.22^{\mathrm{b}}$ & $38.35 \pm 6.18^{\mathrm{c}}$ & $30.17 \pm 7.44^{\mathrm{a}}$ \\
$(\mathrm{cm})$ & $(32.55-51.55)$ & $(29.02-47.06)$ & $(27.18-42.28)$ & $(32.30-50.22)$ \\
$\mathrm{pH}$ & $7.45 \pm 2.14$ & $7.61 \pm 2.42$ & $7.48 \pm 2.11$ & $7.55 \pm 2.12$ \\
& $(6.55-8.85)$ & $(6.50-8.86)$ & $(6.50-8.78)$ & $(6.45-8.66)$ \\
Dissolve oxygen & $5.14 \pm 1.51$ & $5.27 \pm 1.28$ & $4.98 \pm 1.22$ & $5.05 \pm 1.25$ \\
(mg.L-1) & $(4.15-8.22)$ & $(4.04-7.55)$ & $(4.38-7.65)$ & $(4.44-7.75)$ \\
Alkalinity (mg.L- & $111.12 \pm 10.04^{\mathrm{d}}$ & $121.33 \pm 10.22^{\mathrm{b}}$ & $126.55 \pm 9.44^{\mathrm{a}}$ & $116.52 \pm 9.57^{\mathrm{c}}$ \\
1) $^{-}$ & $(101.24-136.33)$ & $(108.24-$ & $(111.27-$ & $(106.18-$ \\
& & $146.42)$ & $156.24)$ & $138.14)$ \\
\hline
\end{tabular}

Figure with different superscripts in the same row differed significantly $(P>0.05)$. Figures in the parenthesis indicate the range.

It A significant rise in $\mathrm{pH}$ during pre-monsoon; followed by a drop in winter was noted in the experimental beel. The mean dissolved oxygen (DO) of the experimental beel did not differ significantly $(\mathrm{P}>0.05)$. But total alkalinity of the experimental beel differed significantly $(\mathrm{P}<0.05)$.

\section{Macrophytes}

A total number of 14 species belonging 14 genera and 12 families of aquatic weeds were identified from the surveyed beel (Table 3). The Macrophytes consisted of 11 families in the concerned four beels viz.,Lemnaceae, Pontederiaceae, Gramineae, Marsiliaceae, Najadaceae, Compositaceae, Commelinaceae, Convolvulaceae, Nymphaceae, Menyanthaceae and Myrtaesae. A total number of 14 species of marginal and submerged aquatic macrophytes were recorded from the beel. These macrophytes provide shelter to the periphyton and other aquatic insects, and act as a source of nutrition to the aquatic animals. Najas najas was dominant among the identified weeds. The eggs of prawn and different fish species were identified into the $N$. najas and water hyacinth (Eichhornia crassipes) during summer to winter. Water hyacinth usually covered a layer on the surface of Khua in the deep. However, due to changing ecosystem health, using pressure of human consumption and cattle food, the percentage $(\%)$ of the population of aquatic weeds was reduced day by day.

Table 3: The percentage of Aquatic weeds of Charia beel decreasing between 2016 and 2019 .

\begin{tabular}{|c|c|c|c|c|c|}
\hline \multirow{2}{*}{\multicolumn{2}{|c|}{$\begin{array}{l}\text { SL. Type } \\
\text { No }\end{array}$}} & \multirow[t]{2}{*}{ Local \& Scientific name } & \multicolumn{3}{|c|}{$\begin{array}{l}\text { Decreased percentage (\%) of aquatic } \\
\text { weeds between } 2016 \text { and } 2019\end{array}$} \\
\hline & & & 2016-2017 & $2017-2018$ & 2018-2019 \\
\hline 1. & Floating & $\begin{array}{l}\text { Edurkanipana(Wolffia arrhiza) and } \\
\text { Kachuripana(Eichhornia crassipes) }\end{array}$ & 12.22 & 15.51 & 18.88 \\
\hline 2. & Emergent & $\begin{array}{l}\text { Dal(Hudroryza aristota) } \\
\text { and Shusnishak(Marsilea quadrifolia) }\end{array}$ & 12.44 & 16.32 & 19.11 \\
\hline 3. & Submerged & Najas(Najas najas) & 10.25 & 13.12 & 15.22 \\
\hline
\end{tabular}




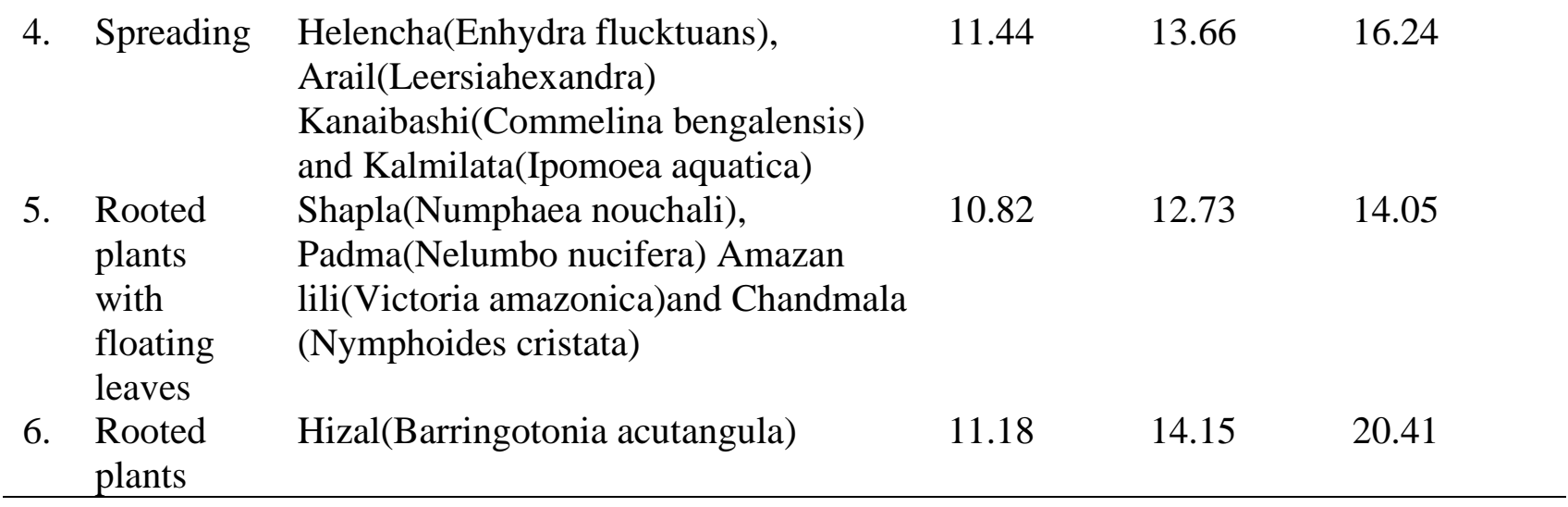

\section{Uses of fishing Craft and gears}

About 10 types of fishing methods were identified in the Charia beel.In 2016, the percentage of catch statistics of beel showed the use of Ber jal, Bua jal, Cast net, Current jal, Dharma jal, Fish trap, FAD,

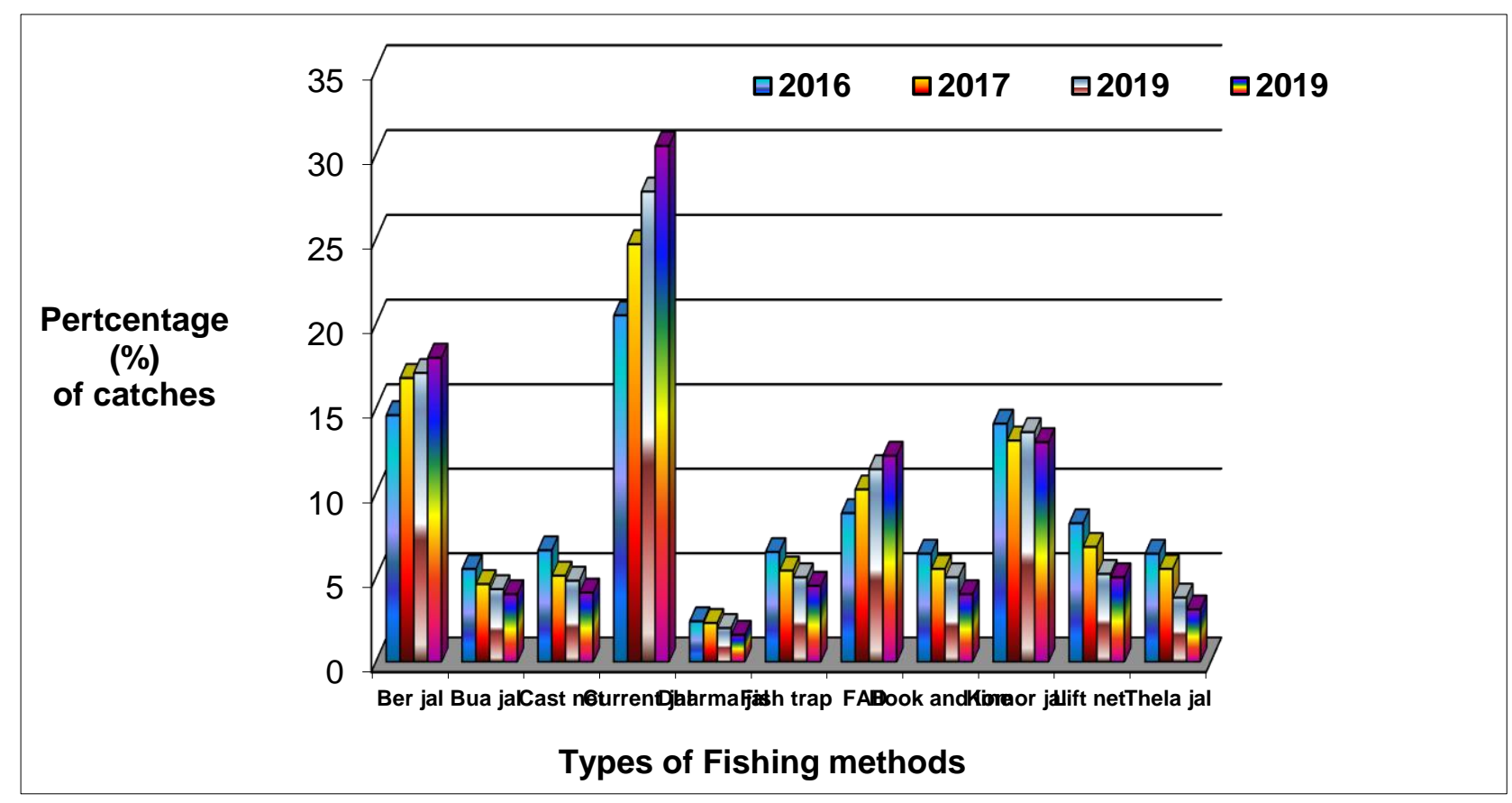

Figure 3. Percent of catch composition by different types of fishing methodsbetween 2016 and 2019 in Charia beel.

Hook and line, Komor jal, Lift net and Thela jal were 14.60, 5.50, 6.60, 20.50, 2.40, $6.50,8.80,6.40,14.1,8.40$ and $6.40 \%$ in 2016 , respectively. The number of using illegal current jal, ber jal (kaperi jal) and FAD were increased in 2017 and 2018. In 2019, illegal using of current jal, ber jal (kaperi jal) and FAD were increased 30.50, 18.00 and 12.2\%, and using Bua jal, Cast net, Dharma jal, Fish trap, Hook and line, Komor jal, Lift net and Thela jal were decreased at the level of $4.00,4.10,1.60,4.50,4.00,13.00,5.00$ and $3.1 \%$, respectively (Fig. 3). There was a significant difference $(\mathrm{P}<0.05)$ in percentages of fish catches among different fishing gears in different years. A significant decreasing trend in 
fish catches was observed with Bua jal, Cast net, Dharma jal, Fish trap, Hook and line, Komor jal, Lift net and Thela jal during the reporting period. A significant decline in the abundances of fish population could be accounted for due to indiscriminate use of illegal fishing gears (Fig. 3).

\section{Catch and catch composition of the beel}

The status of the available position of fauna is furnished in Table 7. The present study indicated the presence of 93 aquatic fauna (83 species of wild fishes, four species of prawn, one species of crabs, one species of snail and four species of turtles) belonging to 65 genera in Charia beel. The annual total catch of the Charia beel was estimated to be 184.52 \pm 55.04 ; $168.12 \pm 56.22,152.29 \pm 56.95$ and 141.65 $\pm 57.66 \mathrm{mt}$ in the year 2016, 2017, 2018 and 2019, respectively consisting of 10 groups (Fig. 4) viz., major carp, minor carp, small fish, Knife fish, snake head, cat fish, small cat fish, spiny eels, prawn, crabs, snail and turtle. Increasing fishing pressure resulting in a gradual reduction in the catches of different groups of fish and other aquatic lives was demonstrated (Table 5).

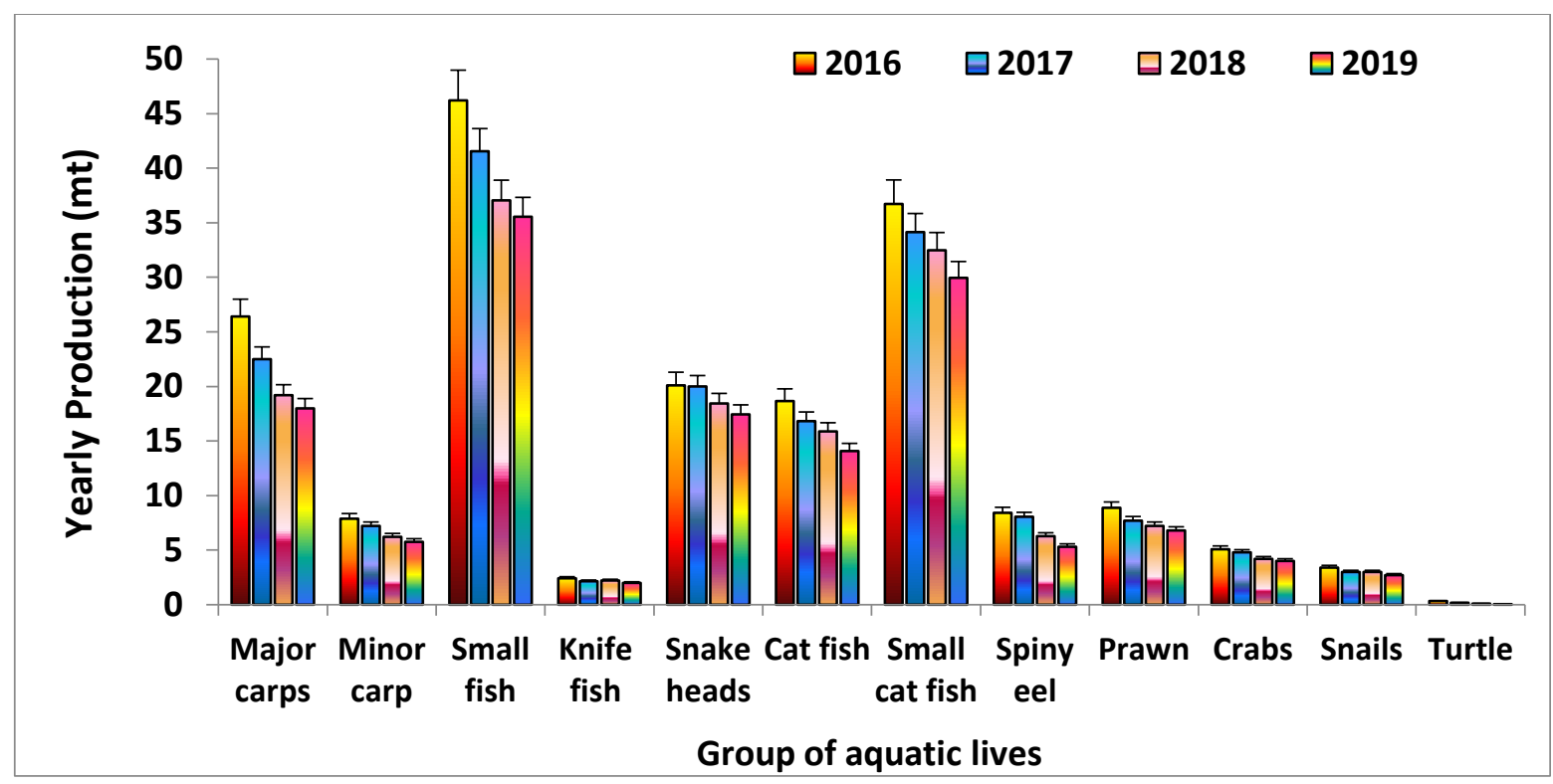

Figure 4: Decreasing production of aquatic fauna in Charia beel between 2016 and 2018, and increasing production in 2019.

The total production of the beel was decreased from $184.52 \pm 55.04 \mathrm{mt}$ to $141.65 \pm$ 57.66 between 2016 and 2019. The percentage of the total production of the beel was declined from $8.88 \% \mathrm{mt}$ to $23.23 \%$ between 2016 and 2019. Decreasing production percentage of different groups of aquatic fauna between 2016 and 2019 in Charia beel was shown in (Fig. 4).

Small fish was the dominant group in the Charia beel between $2016(46.21 \pm 7.06 \mathrm{mt})$ and $2019(35.55 \pm 6.26 \mathrm{mt})$ and small cat fish was recorded to be the second-highest production $36.72 \pm 7.30 \mathrm{mt}$ and $29.95 \pm 6.11 \mathrm{mt}$ in the same period. The catches of all the groups of fishes, crabs, snails and turtles were higher in 2016 but gradually declined between 2017 and 2019 (Fig. 4). 
The status of the 91 aquatic wild lives of the Charia beel was ranked as different status. Important Six (7.0 \%) species such as Sarpunti (Puntius sarana), Napit (Badis badis), Gajar (Channa marulius) and

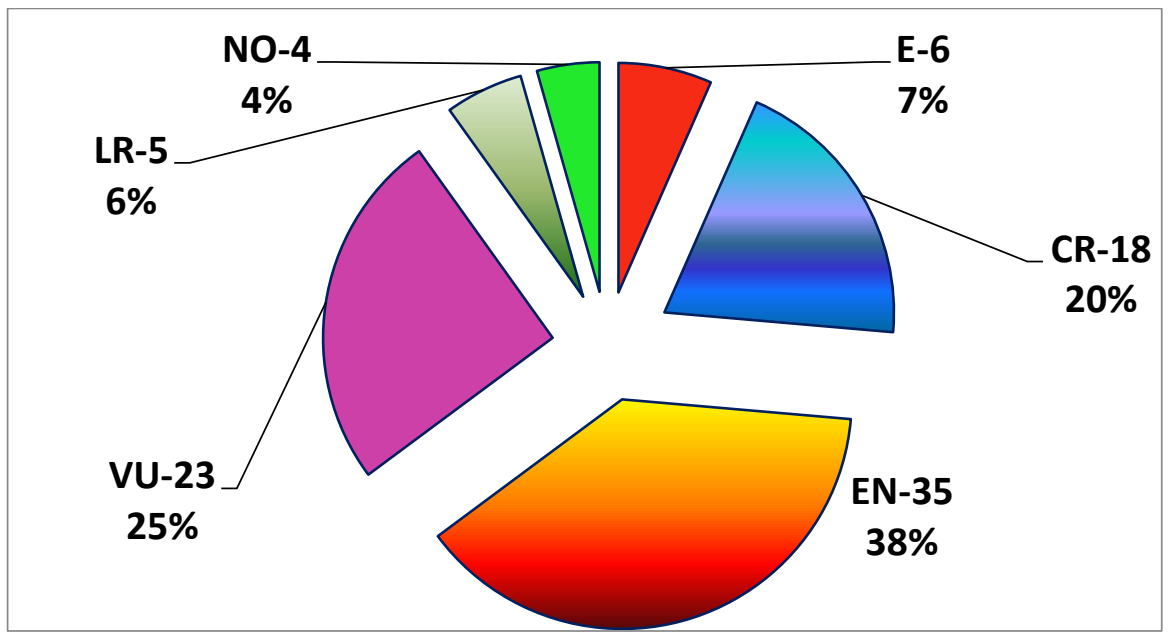

Figure 5. Status of different species of aquatic fauna in the Charia beel during 2016-2019.

Turtles (Kachugatecta,Morenia petersi and Lissemys punctata) were rarely found in the year 2016 but these species were regional extinct (E) between 2017 and 2019. Eighteen (20.0\%) commercial importance species was facing as an extremely higher risk of extinction (Critically endangered, CR) day-by-day. Thirty-five (38.0\%) major commercial importance aquatic wild species of the beel was facing as very high risk of extinction (Endangered, EN), twenty three $(25.0 \%)$ species was facing as high risk of extinction (Vulnerable status, VU), five (5.0\%) species were identified as Lower Risk (LR) and only four (4.0\%) species was Not threatened (NO) position, respectively (Fig. 5 and Table 6).

Table 6: Status and distribution of aquatic lives of Charia beel.

\begin{tabular}{|c|c|c|c|c|c|c|c|}
\hline \multirow{2}{*}{$\begin{array}{l}\text { SL } \\
\text { No }\end{array}$} & \multirow[t]{2}{*}{ Local name } & \multirow[t]{2}{*}{ English name } & \multirow[t]{2}{*}{ Scientific name } & \multicolumn{4}{|c|}{ Status } \\
\hline & & & & 2016 & 2017 & 2018 & 2019 \\
\hline 1 & Puda/Saralpunti & Olive barb & Puntius sarana & EN & CR & $\mathrm{E}$ & $E$ \\
\hline 2 & Napit koi & $\begin{array}{l}\text { Dwarf Chameleon } \\
\text { fish }\end{array}$ & Badis badis & EN & $\mathrm{CR}$ & $\mathrm{CR}$ & $\mathrm{E}$ \\
\hline 3 & Gajar & Giant snake head & Channa marulius & $\mathrm{EN}$ & CR & $\mathrm{E}$ & $\mathrm{E}$ \\
\hline 4 & $\begin{array}{l}\text { Common Roof } \\
\text { Turtile }\end{array}$ & $\begin{array}{l}\text { Common Roof } \\
\text { Turtile }\end{array}$ & Kachuga tecta & CR & $\mathrm{CR}$ & $\mathrm{E}$ & $\mathrm{E}$ \\
\hline 5 & $\begin{array}{l}\text { Bengal Eyed } \\
\text { Turtile }\end{array}$ & $\begin{array}{l}\text { Bengal Eyed } \\
\text { Turtile }\end{array}$ & Morenia petersi & $\mathrm{CR}$ & $\mathrm{CR}$ & $\mathrm{E}$ & $\mathrm{E}$ \\
\hline 6 & Reptile & Spotted Flapshell & Lissemys punctata & CR & $\mathrm{CR}$ & $\mathrm{CR}$ & $\mathrm{E}$ \\
\hline 7 & Bhagna & Labeo & Cirrhinus reba & EN & $\mathrm{EN}$ & EN & CR \\
\hline 8 & Along & Bengal barb & Bengala elanga & $\mathrm{EN}$ & $\mathrm{EN}$ & $\mathrm{E}$ & $\mathrm{CR}$ \\
\hline 9 & Laubuca & Indian Glass-barb & Chela laubuca & EN & $\mathrm{EN}$ & EN & $\mathrm{CR}$ \\
\hline 10 & Bhagna & Reba carp & Cirrhinus reba & EN & $\mathrm{EN}$ & EN & $\mathrm{CR}$ \\
\hline 11 & Dhela & Cotio & Rohtee cotio & EN & $\mathrm{CR}$ & $\mathrm{CR}$ & $\mathrm{CR}$ \\
\hline 12 & Batasi & IndianPotasi & $\begin{array}{l}\text { Pseudeutropius } \\
\text { atherinoides }\end{array}$ & VU & $\mathrm{EN}$ & EN & $\mathrm{CR}$ \\
\hline 13 & Chola punti & Chola barb & Puntius chola & VU & $\mathrm{EN}$ & EN & CR \\
\hline
\end{tabular}




\begin{tabular}{|c|c|c|c|c|c|c|}
\hline 14 & Chola punti & Short leg Prawn & $\begin{array}{l}\text { Machrobrachium } \\
\text { mirabile }\end{array}$ & VU & $\mathrm{EN}$ & $\mathrm{EN}$ \\
\hline 15 & Baghair & Gangetic Goonch & Bagarius yarrellii & VU & $\mathrm{EN}$ & $\mathrm{CR}$ \\
\hline 16 & Gulsa & Gangetic Mystus & Mystus cavasius & VU & EN & EN \\
\hline 17 & Gang tengra & Gangetic Gagta & Gagata gagata & VU & $\mathrm{CR}$ & $\mathrm{CR}$ \\
\hline 18 & Modhu pabda & Pabdha cat fish & Ompok pabda & VU & $\mathrm{CR}$ & $\mathrm{CR}$ \\
\hline 19 & Pabda & Pabo catfish & Ompok pabo & VU & $\mathrm{EN}$ & $\mathrm{CR}$ \\
\hline 20 & Ghura chela & Gora Chela & Securicola gora & VU & $\mathrm{EN}$ & $\mathrm{EN}$ \\
\hline 21 & Bhol & Indian trout & Raiamas bola & VU & $\mathrm{EN}$ & EN \\
\hline 22 & Korsula & Corsula Mullet & Rhinomugil corsula & $\mathrm{EN}$ & $\mathrm{EN}$ & $\mathrm{CR}$ \\
\hline 23 & Bata & Bata Labeo & Labeo bata & VU & $\mathrm{CR}$ & $\mathrm{E}$ \\
\hline 24 & Reptile & $\begin{array}{l}\text { Narrow-headed } \\
\text { Softsheel }\end{array}$ & Chiitra indica & $\mathrm{EN}$ & $\mathrm{EN}$ & $\mathrm{CR}$ \\
\hline 25 & Khoksa & Vagra Baril & Barilius vagra & LR & VU & $\begin{array}{l}\mathrm{V} \\
\mathrm{U}\end{array}$ \\
\hline 26 & Calbaus & Black Rohu & Labeo calbasu & VU & VU & $\mathrm{EN}$ \\
\hline 27 & Ghonia & Kuria Labeo & Labeo gonius & VU & $\mathrm{EN}$ & $\mathrm{EN}$ \\
\hline 28 & Kalo bata & Gangetic Latia & Crossocheilus latius & VU & $\mathrm{EN}$ & EN \\
\hline 29 & Jili punti & Golden Barb & Puntius gelius & VU & VU & $\begin{array}{l}\mathrm{V} \\
\mathrm{U}\end{array}$ \\
\hline 30 & Kachki & Ganga River-sprat & Corica soborna & VU & VU & $\begin{array}{l}\mathrm{V} \\
\mathrm{U}\end{array}$ \\
\hline 31 & Mola & Mola Carplet & Amblypharyngodon mola & VU & VU & $\begin{array}{l}\mathrm{V} \\
\mathrm{U}\end{array}$ \\
\hline 32 & Phutani punti & Dwarf Barb & Puntius phutunio & LR & VU & $\begin{array}{l}\text { V } \\
\mathrm{U}\end{array}$ \\
\hline 33 & Jat punti & $\begin{array}{l}\text { SpotfinSwamp } \\
\text { Barb }\end{array}$ & Puntius Sophore & VU & VU & $\mathrm{EN}$ \\
\hline 34 & Fulchela & $\begin{array}{l}\text { Fine Scaled Razzer } \\
\text { Belly Minnow }\end{array}$ & Salmostoma phulo & VU & VU & $\begin{array}{l}\mathrm{V} \\
\mathrm{U}\end{array}$ \\
\hline 35 & Khalisha & Stripled Gourami & Colisa fasciata & VU & VU & EN \\
\hline 36 & Lal khailsha & Dwarf Gourami & Colisa lalia & LR & VU & $\mathrm{EN}$ \\
\hline 37 & Chuna Khalisha & Sunset Gourami & Colisa sota & VU & VU & EN \\
\hline 38 & Kanpona & Esuarine Ricefish & Oryzias melastigma & VU & VU & $\mathrm{EN}$ \\
\hline 39 & Mini & Mottled Nandas & Nundas nandus & $\mathrm{EN}$ & $\mathrm{EN}$ & $\mathrm{EN}$ \\
\hline 40 & Rani/Botya & Necktie Loach & Botia Dario & VU & VU & EN \\
\hline 41 & Kakila & $\begin{array}{l}\text { Fresh Water } \\
\text { Garfish }\end{array}$ & Xenentodon cancila & VU & VU & $\mathrm{EN}$ \\
\hline 42 & Potka & Ocellated Pufferfish & Tetrodon cutcutia & VU & VU & EN \\
\hline 43 & Chitol & $\begin{array}{l}\text { Humped } \\
\text { Featherback }\end{array}$ & Notopterus chitala & $\mathrm{EN}$ & $\mathrm{EN}$ & EN \\
\hline 44 & Shol & $\begin{array}{l}\text { Striped snake } \\
\text { headed }\end{array}$ & Channa striatus & VU & VU & $\begin{array}{l}\mathrm{V} \\
\mathrm{U}\end{array}$ \\
\hline 45 & Koi & Climbing Perch & Anabas testudineus & VU & VU & $\mathrm{EN}$ \\
\hline 46 & Neftani & Indian Paradise fish & Ctenops nobiilis & $\mathrm{EN}$ & $\mathrm{EN}$ & EN \\
\hline 47 & Ayre & $\begin{array}{l}\text { Long Whiskered } \\
\text { Catfish }\end{array}$ & Aorichthys aor & $\mathrm{EN}$ & $\mathrm{EN}$ & $\mathrm{EN}$ \\
\hline 48 & Guzia & GiantRiver Catfish & Aorichthys seenghala & $\mathrm{EN}$ & $\mathrm{EN}$ & EN \\
\hline 49 & Rita & Rita & Rita rita & $\mathrm{EN}$ & $\mathrm{EN}$ & $\mathrm{EN}$ \\
\hline 50 & Kani papda & Indian butter cat & Ompok bimaculatus & $\mathrm{EN}$ & $\mathrm{EN}$ & $\mathrm{EN}$ \\
\hline
\end{tabular}


fish

\begin{tabular}{|c|c|c|c|c|c|c|}
\hline 51 & Kajuli & Jamuna Ailia & Ailia coila & VU & $\mathrm{EN}$ & $\mathrm{EN}$ \\
\hline 52 & Bacha & Batchwa Bacha & Eutropiichthys vacha & VU & $\mathrm{EN}$ & $\mathrm{EN}$ \\
\hline 53 & Gharua & Garua Bacha & Clupisoma garua & VU & $\mathrm{EN}$ & $\mathrm{EN}$ \\
\hline 54 & Magur & Magur & Clarius batrachus & VU & VU & $\mathrm{EN}$ \\
\hline 55 & Baim & Tire-track Spinyeel & Mastacembalus armatus & VU & $\mathrm{EN}$ & $\mathrm{EN}$ \\
\hline 56 & Kuicha & GangeticMudeel & Monopterus cuchia & VU & $\mathrm{EN}$ & $\mathrm{EN}$ \\
\hline 57 & Tara Baim & One-stripe Spinyeel & Macrognathus aral & VU & VU & $\mathrm{EN}$ \\
\hline 58 & Galda isa & $\begin{array}{l}\text { Giant fresh water } \\
\text { prawn }\end{array}$ & $\begin{array}{l}\text { Machrobrachium } \\
\text { rosenbergii }\end{array}$ & VU & $\mathrm{EN}$ & $\mathrm{EN}$ \\
\hline 59 & Snail & - & Lamellidens marginalis & VU & VU & $\begin{array}{l}\mathrm{V} \\
\mathrm{U}\end{array}$ \\
\hline 60 & Catla & Catla & Catla catla & LR & LR & $\begin{array}{l}\mathrm{V} \\
\mathrm{U}\end{array}$ \\
\hline 61 & Rui & Rohu & Labeo rohita & LR & LR & $\begin{array}{l}\mathrm{V} \\
\mathrm{U}\end{array}$ \\
\hline 62 & Mrigal & Mrigal & Cirrhinus cirrhosus & LR & LR & $\begin{array}{l}\text { V } \\
\mathrm{U}\end{array}$ \\
\hline 63 & Taka punti & Rosy Barb & Puntius conchonius & LR & LR & $\begin{array}{l}\text { V } \\
\mathrm{U}\end{array}$ \\
\hline 64 & Tit punti & Ticto Barb & Puntius ticto & LR & LR & LR \\
\hline 65 & Teri punti & Onespot Barb & Puntius terio & LR & LR & $\begin{array}{l}\mathrm{V} \\
\mathrm{U}\end{array}$ \\
\hline 66 & Darkina & Flying Barb & Esomus danricus & LR & LR & VU \\
\hline 67 & Chapila & Indian River Shad & Gadusia chapra & LR & LR & VU \\
\hline 68 & Nama chanda & $\begin{array}{l}\text { Elongate Glasds- } \\
\text { perchlet }\end{array}$ & Chanda nama & LR & LR & VU \\
\hline 69 & Kata chanda & $\begin{array}{l}\text { Himalayan Glassy } \\
\text { Perchlet }\end{array}$ & Pseudambasis bacuculis & LR & LR & VU \\
\hline 70 & Kachki & Ganga River-sprat & Corica soborna & LR & LR & VU \\
\hline 71 & Ranga chanda & Indian Glassy Fish & Pseudambasis ranga & LR & LR & VU \\
\hline 72 & Gachua & Asiatic snakehead & Channa gachua & VU & VU & VU \\
\hline 73 & Taki & Spotted snake head & Channa punctatus & LR & LR & VU \\
\hline 74 & Boal & Fresh Water Shark & Wallago attu & LR & VU & VU \\
\hline 75 & Tengra & $\begin{array}{l}\text { Striped Dwarf } \\
\text { Catfish }\end{array}$ & Mystus vitttus & LR & VU & VU \\
\hline 76 & Anju & Zebra fish & Brachydanio rerio & LR & VU & VU \\
\hline 77 & Singi & Stinging Catfish & Heteropneustes fossilis & LR & LR & VU \\
\hline 78 & Guchi baim & Striped Spinyeel & Macrognathus pancalus & LR & VU & VU \\
\hline 79 & Foli & Grey Featherback & Notopterus notopterus & LR & VU & VU \\
\hline 80 & Gutum & Guntea Loach & Lepidocephalus gontea & LR & LR & LR \\
\hline 81 & Gura chingri & BirmaRiver Prawn & $\begin{array}{l}\text { Machrobrachium } \\
\text { birmanicum }\end{array}$ & LR & LR & LR \\
\hline 82 & Kakra & - & Stylla serrata & LR & LR & LR \\
\hline 83 & Common carp & Scale carp & Cyprinus carpio & NO & NO & $\mathrm{NO}$ \\
\hline 84 & Silver carp & Silver carp & $\begin{array}{l}\text { Hypophthalmicichthys } \\
\text { molitrix }\end{array}$ & NO & NO & LR \\
\hline 85 & Bujuri & Tengra Mystus & Mystus tengra & NO & LR & LR \\
\hline 86 & Grass carp & Grass carp & Ctenopharyngodon idellus & NO & NO & LR \\
\hline 87 & Nona tengra & Long-whiskered & Mystus gulio & LR & LR & LR \\
\hline
\end{tabular}


Catfish

88 Gkatakia chingri

DimuaRiver Prawn

Machrobrachium

villosimanus

89 Bala

Tank Goby

Glossogobus giuris

NO NO NO NO

90 Thai sarpunti

Silver Barb

Puntius gonionotus

NO NO NO NO

91 Shotka chingri

MonsoonRiver

Prawn

Machrobrachium

malcolmsnii

NO NO NO NO

NO NO NO NO

(Status code: E- Extinct, CR-Critically Endangered, EN-Endangered, VU-Vulnerable, LR- Lower risk, NO-Not threatened) Shannon index was followed to compare the trend among different years by Shannon index method and six codes of IUCN followed to categorize the status of the beel.

During investigation periods, fresh water pearl-bearing mussels (Bivalve, Lamellidens marginalis) were recorded in the experimental beel. Shells of bivalve were utilized by rural people for the production of lime which was utilized in aquaculture and agriculture land, and consumed with betel leaves and nuts. Wildlife includes, amphibians (Buffo melanostictus, Rana tigerina, Rana limnocharis, Rana cyanophyctis and Salamandra salamondra) aves (whistling duck, great crested grebe, great cormorant, red-crested pochard, water cock, swamphen, great black-headed gull, gray-headed fish eagle, curlew, spotted redshank) and mammals (musk shrew, fishing cat, small Indian jackal, flying fox) were identified.

\section{Discussion}

The physico-chemical factors were found to be more or less in the normal range in the Charia beel which is agreed by APHA (1998). Water temperature of the beel showed an increasing trend in monsoon and post-monsoon season and a decreasing trend in winter which is supported by Mathew (1975). Transparency was consistently higher in the deeper portion of the beel, possibly due to the stagnancy of water. Rahman (1992) stated that the transparency of productive water bodies should be $40 \mathrm{~cm}$ or less. The uniformly average value of oxygen range (4.05 - $\left.7.65 \mathrm{mg} . \mathrm{L}^{-1}\right)$ and $\mathrm{pH}(6.45-8.86)$ as noted in the beel agrees well with the findings of Boyd, C. E. (1982). An alkalinity level of the beel was medium to high (Clesceri et al., 1989).

A total number of 14 species of marginal and submerged vegetation was observed in the floodplain and beel, which are comparable with the finding of Sugunan and Bhattacharjea (2000) in the case of the floodplain of the Brahmaputra basin. The swamp forests, mainly represented by hijal tree (Barringtonia acutangula) have been reduced to a few small patches in the surveyed area.

The fishing effort with various types of fishing methods such as seine net (especially kaperi jal), gill net (current jal) and FAD was increased between the year 2016 and 2018 but the use of current jal was increased dramatically during the same period. As a result, the average number of fishes and other aquatic lives declined in the surveyed beel and its floodplain. Haroon et al. (2002) reported eighteen types of fishing gears recorded from the Sylhet sub-basin and thirteen types from Mymensingh sub-basin which are very similar to this study. Sugunan and Bhattacharjia (2000) found a wide variety of fishing methods employed in the beels of Assam, India which are very similar to the present study. Cast net 
(Jaki jal) was used the whole year in the beel. It is a very popular fishing method and used all over Bangladesh (Ahmad, 1962).

The catch statistics indicate that the fishing pressure of the beel was increased rapidly in the year 2016 to 2019. As a result, a decreasing trend in production percentage of the beel was pronounced within four years which was very similar to the report of Moyle and Leidy (1992). According to them, worldwide $20 \%$ of all freshwater species are extinct, endangered or vulnerable. The total catch statistics of aquatic lives in the surveyed beel indicated that percentage of a different group of aquatic lives was sharply decreased within four years which are very similar to the study of Chakraborty et al, $(2021 ; 2019 ; 2010)$; Chakraborty (2009; 2010); Chakraborty and Mirza (2007). Shannon index (Shannon, 1948) was used to identify the present status of the Charia beel. But six indicators of IUCN (2000) were used for ranking of aquatic fauna of the beel. Commercial important Fish species Local sarpunti (Puntius sarana), Napit (Badis badis), Gajar (Channa marulius) and Reptiles (Kachuga tecta,Morenia petersi and Lissemys punctata) were rarely found in the year of 2016 in the Charia beel. However, these species were regionally extinct between 2017 and 2019. Eighteen commercially important aquatic species were facing as an extremely higher risk of extinction (CR) day-by-day. About 35 commercial importances aquatic wild species of the beel was facing an extremely high risk of extinction (EN), 23 aquatic wild species were Vulnerable status, five species were identified as Lower Risk and only four species were Not threatened position, respectively. According to IUCN 1998, Bangladesh about 56 freshwater fish species are critically or somewhat endangered. Due to over-exploitation and various ecological changes in natural aquatic ecosystem health such as beel and its floodplain, commercially important aquatic lives were on the verge of extinction which is in agreement with the findings of Prakash et al, (2020) and Sarker(1993).

During winter season, turtles(Morenia petersi, Kachuga tecta Lissemys punctata and Chiitra indica) were caught in the beel and its floodplain. Khan (1982) reported that Kachuga tecta are mainly distributed between the stretches of the Ganges River and the Brahmaputra River. Bengal Eyed turtle, Morenia petersi was found in the beel and its floodplain. Das (1991) mentioned that the occurrence Bengal Eyed turtle, Morenia petersi was in Assam of India. Turtles of the surveyed beel and its floodplain were declined because of dewaterization of its habitat for irrigation and destruction of its breeding ground and nesting sites. Over exploitation for local consumption and foreign trade indiscriminately poses a threat to all species of turtles as well. The population of bivalve, Lamellidens marginalis was found in the beel and floodplain, had also decreased which is consistent with the observation ofAli (1991).

The study indicated that the aquatic lives of the beel were subjected to over fishing resulting in gradual decline in the aquatic population. In addition, aquatic ecosystem health is changing due to global effect, construction of flood control barrage, soil erosion, siltation and drainage structures and agro-chemicals. Domestic organic wastes (sewage) directly or indirectly passing through canals or drains to the beel were polluted the aquatic ecosystem health. The genetic stock structure of aquatic populations was reduced due to pollution and destructive fishing practices (Mazid and Hussain, 1995). Indiscriminate killing of fish occurred due to the use of pesticides in improper doses, use of forbidden chemicals, and 
aerial spray of chemicals as used in paddy field which is very much similar to the observation of Mazid (2002) and Chakraborty et al.(2021).

Indiscriminate destructive fishing practices was caused havoc to the aquatic biodiversity of the beel. As a result, the ecosystem health and biological diversity of the beel deteriorated at an unprecedented rate (Hussain and Hossain, 1999; Chakraborty et al.2021). Intervention to control floods, adoption of new agricultural technologies and construction of road networks were altered the ecology of beel significantly which supported the views of Khan (1993) and Ali (1991). The stock of the wildlife brood fishes in their breeding ground was also suffered significant damages resulting in a reduction of biodiversity as noted by Nishat (1993), Zaman (1993) and Chakraborty et al. (2010).

The local beel management committee developed a working frame work on sharing benefits, developing rules and regulations for beel resource management. Fortnightly meetings were regularly by the beel management committee to monitor and progress of the beel nursery practice. Participation of local member of the community and their active involvement played an important role in the overall management of beel nursery and beel resource (Chakraborty et al., 2021).

\section{Conclusion and Suggestion}

For better management to save the stock of aquatic species in this beel, regular stocking of fingerlings with a team of local management committee is needed to develop a working frame-work. The deep area of the beel must be declared as sanctuaries to protect the aquatic lives in all season, strict enforcement of fish Act-1950, ensured unplanned construction of flood control, embankments, drainage system and sluice gates, conversion of inundated land to cropland (reducing water area); and controlling use of pesticides and agrochemicals in the floodplains area of the beel; can save and change the ecosystem and the production level of the beel; and can ensure food security of the people of Bangladesh.

\section{Acknowledgements}

None.

\section{Conflict of Interest}

None.

Funding:

None.

\section{References}

Ahmad, N. (1962). Fishing gear of East Pakistan. Government of East Pakistan. Directorate of Fisheries. Dhaka, 37 p. 
Allendroff, F. W. (1988). Conservation Biology of Fishes. Conservation Biology, 2(2), 145148.

Ali, M.Y. (1991). Towards sustainable development: fisheries resources of Bangladesh International Union for Conservation of nature and Natural Resources. The World Conservation Union. National Conservation Strategy of Bangladesh and Bangladesh Agricultural Research Council.

APHA (1998). Standard methods for the examination of water and wastewater, 20th edition, American Public Health Association, Washington, DC.

Ashok K. V. (2017a). Necessity of Ecological Balance for Widespread Biodiversity. Indian Journal of Biology. 4(2), 158-160. http://dx.doi.org/10.21088/ijb.2394.1391.4217.15 (2017b). Genetic Diversity as Buffer in Biodiversity. Indian Journal of Biology. 4(1), 61-63. http://dx.doi.org/ 10.21088/ ijb.2394.1391.4117.9

(2019). Sustainable Development and Environmental Ethics. International Journal on Environmental Sciences. 10 (1), 1-5.

Boyd, C. E. (1982). Water Quality Management for Pond Fish Culture. Elsevier Scientific Publishing Co..

Chakraborty B. K., Bhattacharjee, S. and Muniya, S. (2021). A Study of aquatic biodiversity of Shuthi-Shaiduli river of Bangladesh. International Journal of Biological Innovations. 3(1), 58-67.

Chakraborty B.K., Shahroz M.H., Bhuiyan A.B., Bhattacharjee S. and Chattoraj S. (2019). Status of Indian major carps spawns in the Halda River along with marketing and economic condition of the Fishers and related collectors. International Journal of Biological Innovations. 1 (2), 40-50. https://doi.org/10.46505/IJBI.2019.1202.

Chakraborty, B. K., S. A. Azad, B. Bormon, M. Ahmed and A. M. O. Faruque (2010). To investigate the technical and co-management aspects of mud eel (Monopterus cuchia) culture by ethnic (Adivasi) communities in the Northern Bangladesh, J. Crop and Weed, India, 6(2), 19-25.

Chakraborty, B. K. and M. J. A. Mirza (2010). Status of Aquatic Resources in Someswari River in Northern Bangladesh. J. Asian Fish. Sci. Manila, Philippines23(2), 174-193.

Chakraborty B. K. (2009). Aquatic biodiversity of Someswari and Nethai River and Gharia and Nidaya Beel of Northern Bangladesh. In: Takumi K. Nakamura (ed.).

Aquaculture Research Progress, Nova Science Publishers, New York, USA, pp. 32313268.

Chakraborty, B. K. (2009). Aquatic biodiversity of Someswari and Nethai River; Gharia and Nidaya Beel of Northern Bangladesh. In Aquaculture Research Progress, Nova Science Publishers, New York, USA, pp. 3231-268.

Chakraborty, B. K. and M. J. A. Mirza (2007). Aquatic biodiversity of Someswari River in Bangladesh. Proc. Zool. Soc .Kolkata, India, 60(2), 37-44.

Clesceri, L. S., A. E. Greenberg and R. R. Trussell (1989). Standard Methods of the Examination of Water and Wastewater (17th ed.). American Public Health Association, American Water Works Association and Water Pollution Control Federation, 1015 Washington D. C., USA 20036, pp.10-203.

Crains, M. A. and R. T. Lackey (1992). Biodiversity and management of natural resources. Fisheries, 17(3), 6-10. 
Das, I. (1991). Colour Guide to the turtles and Tortoises of the Indian sub continent. R \& A Pub. Ltd.

Dister, E. (1990). Floodplain protection in central europe. World Wildlife Found (WWF) Institute of Floodplains Ecology Visiting Card, 31, 90.

Duncan, D. B. (1955). Multiple range and multiple F tests. Biometrics, 11(1), 1-42.

Haroon, A. K. Y., G. C. Halder, S. L. Rahman, M. A., Razzaque, M. Alam and S. M. Nurul Amin (2002). Sylhet-Mymensingh Basin Fish Stock Assessment. Final Report. Bangladesh Fisheries Research Institute, Reverine Station, Chandpur, Bangladesh 81 p.

Hussain, M. G. and M. A. Hossain (1999). Controlled breeding technology and step for conservation of gene pool of certain endangered fish species of Bangladesh. Fish. News Letter, 7(1-3), 2-3.

IUCN, (1998). List of threatened animals of Bangladesh. Paper presented in the Special Workshop on Bangladesh Red Book of Threatened Animals, 22 February 1998, Dhaka, Bangldesh.

IUCN. (2000). Red book of threatened Fishes of Bangladesh. IUCN - The World Conservation Union xii+116 p.

Khan, H. R. (1993). Water development activities and their impacts on wetlands.In Freshwater wetlands in Bangladesh: Issues and Approaches for management. IUCN, Gland Switzerland. pp 23-32.

Khan, R. (1982). Chelonians of Bangladesh and their conservation. Journal of the Bombay Natural History Society. Bombay, 79(1), 110-116.

Mathew, P. W. (1975). Limnology and productivity of Govindgarh Lake, Maddya Prodesh, India. J. Inland Fish. Soc. India, 11, 16-24.

Mazid M. A. and M. S. Hossain, (1995). Development of fisheries resources in floodplains. FRI publication No. 12. Fisheries Research Institute, Mymensingh, Bangladesh.

Mazid M. A. (2002). Development of Fisheries in Bangladesh. In Plans and Strategic for Income Generation and Poverty Alleviation. Fisheries Research Institute, Mymensingh, Bangladesh. pp. 78-79.

Moyle, P. B., \& Leidy, R. A. (1992). Loss of biodiversity in aquatic ecosystems: evidence from fish faunas. In Conservation biology (pp. 127-169). Springer, Boston, MA.

Nishat, A. (1993). Freshwater wetlands in Bangladesh: status and issues. In Freshwater wetlands in Bangladesh: Issues and Approaches for management. IUCN, Gland Switzerland, pp. 9- 22.

Noss, R. F. (1983). A regional landscape approach to maintain diversity. BioScience, 33(11), 700-706.

Nuruzzaman, A.K.M. 1997. National Conservation Study, Fish Fauna of Tanguar Haor, Dhaka.

Prakash S. and Verma A. K. (2020). Effect of Organophosphorus Pesticides on Biomolecules of Fresh Water Fish, Heteropneustes fossilis (Bloch). Indian Journal of Biology. 7(2), 65-69.

Prakash S., Kumar A., Prakash S. and Mishra B.K. 2020. A Survey of Fish Fauna of Rapti River, Balrampur (U.P.), India. International Journal of Biological Innovations. 2(1), 76-81. https://doi.org/10.46505/IJBI.2020.2110 
Rahman, M. S. (1992). Water quality Management in Aquaculture.BARC Prokashana, 66, Mohakhali, Dhaka 1212, Bangladesh.

Shannon, C. E. (1948). A mathematical theory of communication. The Bell system technical journal, 27(3), 379-423.

Sarker, S. U. (1993). Faunal diversity and their conservation in freshwater wetlands. In Freshwater wetlands in Bangladesh issues and approaches for management. IUCN, The world Conservation Union, pp.105-122.

Sugunan V. V. and Bhattacharjya B. K. (2000). Ecology and Fisheries of Beels in Assam. Bull. No. 104, CICFRI, Barrackpore-743101, West Bengal.

Verma A. K. (2016). Biodiversity: Its Different Levels and Values. International Journal on Environmental Sciences. 7(2), 143-145.

Verma A. K. (2018). Ecological Balance: An Indispensable Need for Human Survival. Journal of Experimental Zoology, India. 21 (1), 407-409.

Verma A. K. and Prakash S. (2020). Status of Animal Phyla in different Kingdom Systems of Biological Classification. International Journal of Biological Innovations. 2 (2), 149-154. https://doi.org/ 10.46505/ IJBI.2020.2211

Zaman, S. and M. H. (1993). Agricultural development and sustainability of wetlands. In Freshwater wetlands in Bangladesh: Issues and Approaches for management. IUCN, Gland Switzerland, pp. 63-178.

Zar, J. H. (1984). Biostatistics. Prentice-Hall, Inc. Englewood Cliffs, New Jersey, USA. 718 p. 